\title{
WADAH HIBURAN, INOVASI DAN EDUKASI TATABOGA TAHU TEMPE DI SEMANAN
}

\author{
Gabriella $^{1)}$, Diah Anggraini ${ }^{21}$ \\ 1)Program Studi S1 Arsitektur, Fakultas Teknik, Universitas Tarumanagara, \\ michaella.gabriella@gmail.com \\ 2)Program Studi S1 Arsitektur, Fakultas Teknik, Universitas Tarumanagara, diaha@ft.untar.ac.id
}

Masuk: 13-07-2020, revisi: 28-07-2020, diterima untuk diterbitkan: 24-09-2020

\begin{abstract}
Abstrak
Meskipun tingkat konsumsi tahu tempe sangat tinggi, dan Indonesia saat ini menjadi negara produsen tahu dan tempe terbesar di dunia, namun para pengrajin tahu tempe masih mengalami permasalahan dengan harga bahan baku kedelai yang fluktuatif, sementara harga jual produknya cenderung tetap, sehingga kesejahteraan para pengrajin tahu tempe di DKI Jakarta, sulit meningkat. Hal ini juga terjadi di Perkampungan Pengrajin Tahu Tempe di Semanan, Jakarta Barat. Studi ini bertujuan untuk meningkatkan kemampuan pengrajin tahu tempe di Semanan melalui penyediaan wadah riset pengembangan dan inovasi produk olahan tempe dan tahu, bantuan pemasaran dan wadah edukasi bagi komunitas terkait, di samping dapat menyediakan wadah interaksi sosial bagi masyarakat lokal dari berbagai macam latar belakang sosial, ekonomi, dan budaya agar terbentuk komunitas yang berkarakter, menyatu dan berkelanjutan. Sebagai third place, tapak yang akan menjadi kasus studi ini berada di antara kawasan perumahan (first place) dan kawasan pertanian, industri, dan perdagangan (second place) dengan aksesibilitas yang mudah dari kedua kawasan tersebut. Metode desain mengacu pada pendekatan Responses to Site, dengan pengolahan desainnya mengutamakan prinsip porositas yang menjadi salah satu aspek dalam open architecture. Studi ini menghasilkan konsep dan perancangan bangunan third place dengan tiga fasilitas utama, yaitu community center yang terdiri dari ruang komunal untuk bersosialisasi dan berinteraksi pengunjung dan dapur food research and development untuk sarana berinovasi dan pengembangan produk makanan dari tempe, ruang terbuka publik yang difungsikan untuk kegiatan bermain, berolahraga dan penyelenggaraan berbagai event, serta food market yang menjual makanan berbasis tempe dan tahu.
\end{abstract}

Kata kunci: inovasi; pengrajin; porositas; tahu tempe

\begin{abstract}
Even thought the level of consumption of tahu tempe is very high, and Indonesia is currently the largest tahu and tempe producer country in the world, but the tahu tempe craftsmen still experiencing problems with fluctuating soybean raw material prices, while the selling price of their products tends to remain, so that the welfare of the tahu tempe craftsmen in DKI Jakarta, is difficult to increase. This also happened to tahu tempe craftsmen in Tahu Tempe Village in Semanan, West Jakarta. This study aims to improve the ability of tahu tempe craftsmen in Semanan by providing a research and development place for tahu and tempe products, marketing assistance and an educational place for related communities, in addition to being able to provide a place for social interaction for local communities from a variety of social, economic and cultural backgrounds to form a community that has character, united and sustainable. As the third place in Semanan, the site was chosen between the residential neighborhood (first place) and the agriculture, industrial, and trade area (second place) with easy accessibility of the two regions. The design method refers to the Responses to Site approach, with the processing of the design prioritizing the principle of porosity which is one aspect of open architecture. This study resulted in concept and design of the third place building with three main facilities, namely community center consisting of a communal space for socializing and interacting visitors and a food research and development kitchen for a means of innovating and developing food products from tempe and tofu, public outdoor space that is used for playing activities, exercising and organizing various events, as well as food market that sells tempe and tahu based foods.
\end{abstract}

Keywords: craftsmen; inovation; porosity; tahu tempe 


\section{PENDAHULUAN}

\section{Latar Belakang}

Dalam sejarah kuliner di Indonesia khususnya masyarakat Jawa, tercatat memiliki makanan tradisional yang berperan penting menyelamatkan kekurangan gizi pada zaman penjajahan, yaitu tahu dan tempe. Kandungan gizi protein yang sangat tinggi menjadikan tahu dan tempe sebagai komoditas bahan makanan penting di Indonesia. Saat ini Indonesia menjadi negara produsen tahu dan tempe terbesar di dunia namun, industri tahu dan tempe tersebut masih bersifat industri kecil dan kebanyakan menggunakan teknologi yang konvensional (disarikan dari Azanella, 2019). Permasalahan yang umum dihadapi oleh produsen industri tahu dan tempe adalah harga bahan makanan tahu dan tempe yang tetap sama di pasar meski harga bahan baku kedelai selalu berfluktuatif (Sicca, 2018). Kondisi ini membuat kesejahteraan ekonomi para pengrajin tahu dan tempe sulit meningkat.

Studi ini mengambil kasus di Permukiman Industri Kecil Semanan yang berada di Kelurahan Semanan, Kecamatan Kalideres, Jakarta Barat. Kawasan ini memiliki sejarah yang berkaitan dengan bertumbuhnya Kelurahan Semanan menjadi sentra industri tahu dan tempe dan dikenal sebagai Perkampungan Tempe. Menurut wakil ketua RT 06, 90\% penduduknya merupakan pengrajin tempe, $6 \%$ pengrajin tahu dan $4 \%$ lainnya bekerja sebagai buruh pabrik dan perkampungan ini telah berdiri sejak 1992 (Sulistiowati, 2018). Melihat permasalahan tersebut, maka sangat diperlukan dukungan untuk membantu meningkatkan kesejahteraan masyarakat melalui pengembangan hasil produksi lokal, bantuan pemasaran, inovasi dan edukasi serta interaksi dan sosialisasi untuk masyarakat.

\section{Tujuan}

Tujuan dari studi ini adalah menghasilkan perancangan arsitektur third place 'Wadah Hiburan, Inovasi dan Edukasi Tataboga Tahu Tempe di Semanan' yang didasarkan pada pemenuhan kebutuhan komunitas pengrajin tahu tempe dan masyarakat Semanan.

\section{Rumusan Permasalahan}

a. Bagaimana penyusunan program aktivitas dalam suatu third place yang dapat membantu meningkatkan kesejahteraan pengrajin dengan mengembangkan produk olahan tahu dan tempe, menjadi wadah pemasaran produk, wadah riset inovasi produk berbasis tahu dan tempe, dan wadah pelatihan untuk meningkatkan kemampuan dan kemandirian komunitas

b. Bagaimana menyusun rancangan arsitektural suatu third place yang dapat menjadi tempat untuk bersosialisasi, rekreasi dan bersantai bagi masyarakat lokal baik mereka yang tinggal di $1^{\text {st }}$ place maupun yang bekerja dan melakukan aktivitas produktif sehari-hari di $2^{\text {nd }}$ place.

\section{KAJIAN LITERATUR}

\section{Tinjauan Isu Permasalahan}

Tahu Tempe sebagai Bahan Makanan Penting di Indonesia

Tempe merupakan makanan asli tanah Jawa yang penemuannya berkaitan dengan produksi tahu karena berasal dari bahan baku yang sama, yaitu kacang kedelai. Dalam sejarah tahu dan tempe di Indonesia, makanan yang kaya akan protein nabati terutama tempe mempunyai peran penting dalam menyelamatkan kurangnya gizi dan kesehatan pada era tanam paksa penjajahan Belanda di abad ke-19. Menurut Sejarawan dan Budayawan Dr. Ong Hok Ham, kebiasaan masyarakat Jawa pada tahun 1810-an dalam memperoleh makanan dari kegiatan berternak, berburu, dan memancing berubah karena adanya kebijakan dari Belanda yang memaksa mereka untuk melakukan program tanam paksa. Kejadian inilah yang membuat masyarakat beralih untuk memperoleh gizi dari protein nabati dan hingga kini membuat Indonesia menjadi negara produsen tahu dan tempe terbesar di dunia (Azanella, 2019). Tempe dan tahu merupakan komoditas bahan makanan penting dengan konsumsi yang cukup tinggi 
dan diminati oleh masyarakat Indonesia, terlihat pada posisi tempe dan tahu yang berada pada posisi 9 dan 10 dari 25 komoditas $^{1}$. Jumlah konsumsi tahu menurut provinsi di Indonesia tahun 2018, DKI Jakarta menduduki posisi kedua terbesar setelah Jawa Timur sedang untuk konsumsi tempe, DKI Jakarta merupakan provinsi dengan posisi keempat terbesar setelah Jawa Timur, DI Yogyakarta, dan Jawa Tengah (Badan Pusat Statistik, SUSENAS, 2018). Hal ini menunjukkan masyarakat DKI Jakarta mempunyai konsumsi dan minat yang tinggi terhadap bahan makanan tahu dan tempe dan menjadikan tahu dan tempe sebagai bahan makanan yang penting di DKI Jakarta. Industri tahu dan tempe tersebar pada setiap bagian kota di DKI Jakarta, hal ini dapat dilihat pada gambar 1 . Studi ini berada di kawasan sentra industri tahu dan tempe, yang mempunyai peran cukup besar di Wilayah Jakarta Barat, yaitu di Pemukiman Industri Kecil Semanan di Kelurahan Semanan, Kecamatan Kalideres.

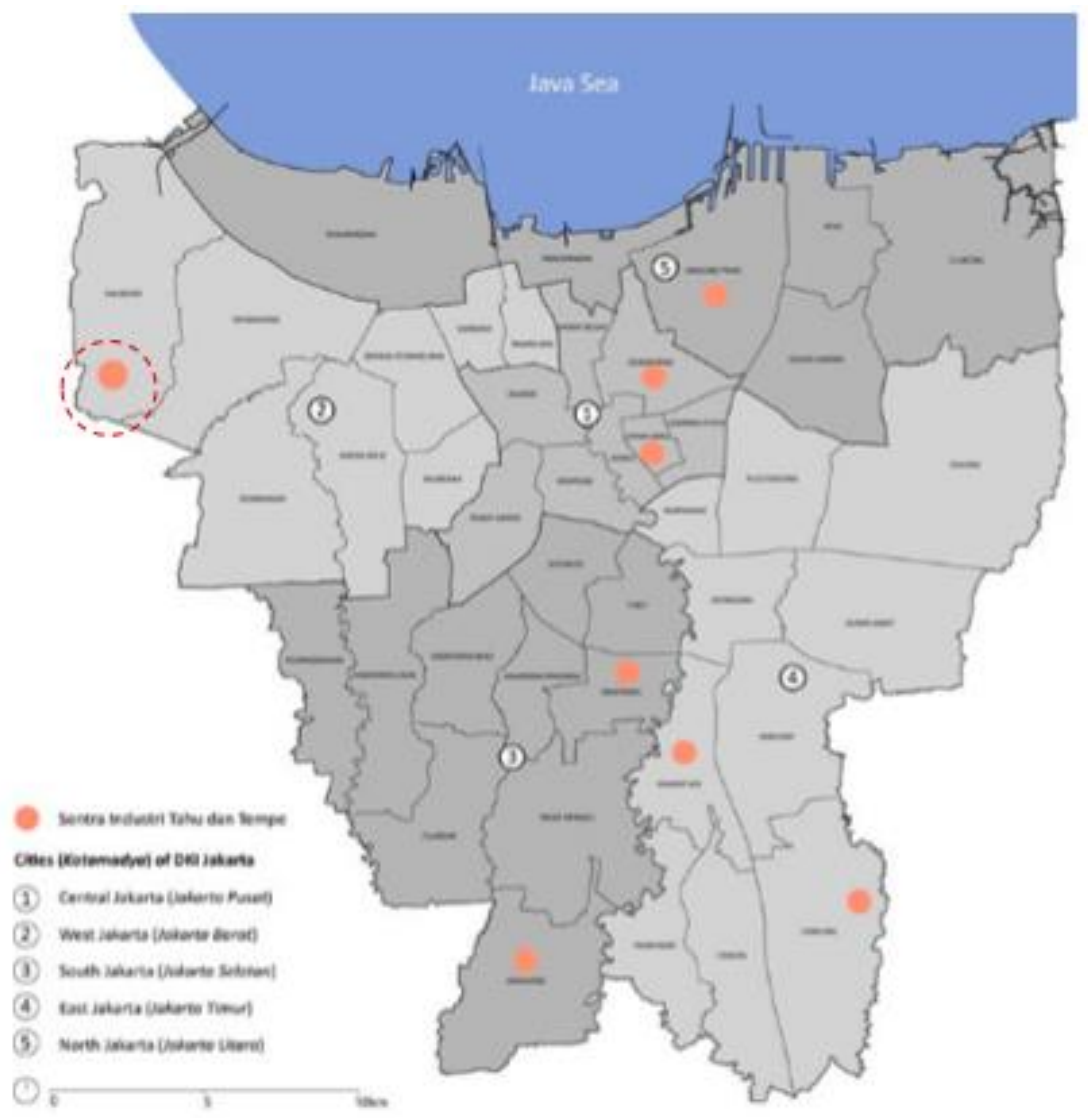

Gambar 1. Peta Sentra Industri Tahu dan Tempe di DKI Jakarta Sumber: Penulis, 2020

\section{Third Place}

Open Architecture sebagai sebuah third place merupakan tempat yang mempertemukan berbagai kalangan masyarakat yang umumnya berasal dari first place (home) dan second place (workplace: sekolah, kantor). Third place di kota digunakan sebagai tempat yang netral, tempat pengunjung berekspresi, bertukar pikiran. Third place menjadi fasilitas di dalam sebuah neighborhood. Berbeda dari first place (home) yang mempunyai ciri: private structured, hierarkis dan terkontrol, tempat berinteraksi antara orang tua, dewasa, remaja dan anak-anak, dan memiliki limited expression, maka second place (workplace) umumnya berciri: wadah hubungan pekerja dan pemberi kerja (employer-employee), rigid, structured, social experience (bertemu dengan teman sekantor), formal, rush-rush-rush (dikejar oleh waktu), dan organized.

\footnotetext{
${ }^{1}$ (Badan Pusat Statistik, SUSENAS, 2018)
} 
Maka Third place, yang bertujuan menjadi wadah interaksi dan bersantai bagi seluruh warga, bersifat: ${ }^{2}$

a. Netral, setiap orang boleh masuk dan tidak mempunyai kewajiban di third place. Orang dapat datang dan pergi begitu saja.

b. Level, semua mempunyai status sosial, hierarki, dan kedudukan yang sama memiliki kedudukan yang sama.

c. Conversation, sebagai aktivitas utamannya dan dengan topik berbagai macam.

d. Accessible, menjadi tempat yang dapat diakses oleh siapa saja dan dapat memenuhi kebutuhan dari penggunanya.

e. Regulars, pengunjung third place merupakan pengunjung regular karena third place merupakan bagian dari komunitas (neighborhood). Hal ini membuat setiap orang mempunyai kedekatan dengan yang lain.

f. Plain and Unpretentious, third place merupakan tempat yang sederhana yang membuat masyarakat datang tanpa keraguan. Hal ini membuat third place terbuka bagi siapa saja.

g. Playful Mood, menjadi tempat yang menyenangkan bagi siapa saja.

Third place mempunyai permasalahan karakter yang bertentangan, yaitu public-not public, paid-unpaid, sell-not sell, regulated-not regulated dan permasalahan ini dalam open architecture dipertemukan dengan melakukan pendekatan desain. ${ }^{3}$ Prinsip open society, open city, open architecture menjadikan sebuah third place tidak melulu dipenuhi oleh fungsi komersial (contoh: gereja, taman, recreation center, gym dan fast food restaurant). Third place menunjukkan karakter Openess yang secara fisik mempunyai ciri: transparent (view), void (internally), accessibility (flow untuk pejalan kaki), dan porosity (mempunyai koneksi terhadap kawasan dan alam) dan secara non-fisik mempunyai ciri, yaitu: Programming (activities), mencampurkan (mix) program, placeness (being place), dan playfulness (informality), ruang yang menyenangkan. ${ }^{4}$

Ruang ketiga harus bisa dirasakan kehadirannya dalam ruang kota (mempunyai konteks urban yang kuat) dan secara arsitektural memenuhi aspek permeabilitas yang memungkinkan rembesan dari pergerakan manusia, mengingat ruang ketiga berada di antara ruang pertama dan ruang kedua. Ruang ketiga untuk kota mempunyai prinsip:

a. Openess: Mempromosikan inklusif (semua orang dapat menggunakan), sebuah tempat bertemu orang asing, permeable space (pergerakan merembes menyebar), dan menjadi tempat untuk bertukar informasi (ruang sosial)

b. Flexibility: Kebebasan untuk mengisi (occupy) ruang tersebut, dan kemungkinan untuk pemprograman hybrid

c. Contextuality: Menjawab kebutuhan masyarakat dan identitas lokal, keseharian, kehidupan, kultur, dan sejarah. ${ }^{5}$

\section{Paradigma Porositas}

Porositas dalam arsitektur mempunyai fungsi yang berkaitan dengan sirkulasi dan fitrasi terhadap lingkungan luar. Keterkaitan dengan kawasan dan alam mendekatkan bangunan dengan konteks kawasan. Terdapat beberapa variasi di dalam konsep porosity yang diterapkan pada bentuk bangunan dalam arsitektur, yaitu: substraction (pengurangan), diagonal porosity, merger sponge, vertical porosity, substitution (penggantian), deviration. (Kotsopoulos, 2007).

\footnotetext{
2 Disarikan dari Kuliah Umum 13 Januari 2020, Suwardana Winata, S.T., M.Arch.

${ }^{3}$ Disarikan dari Kuliah Umum 13 Januari 2020, Suwardana Winata, S.T., M.Arch.

${ }^{4}$ Disarikan dari Kuliah Umum 16 Januari 2020, Suryono Herlambang, S.T., M.Sc.

${ }^{5}$ Disarikan dari Kuliah Umum 16 Januari 2020, Ir. Agustinus Sutanto, M.Arch., M.Sc., PhD.
} 


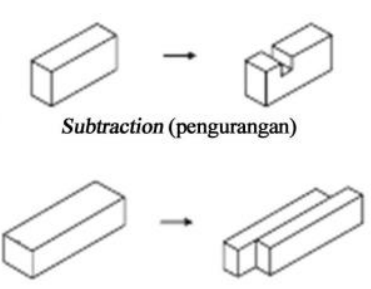

Diagonal Porosity

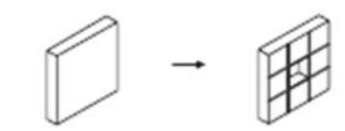

Merger Sponge

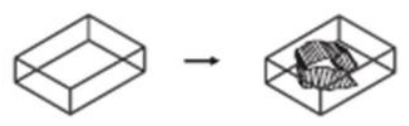

Vertical Porosity

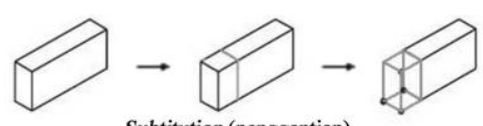

Subtitution (penggantian)

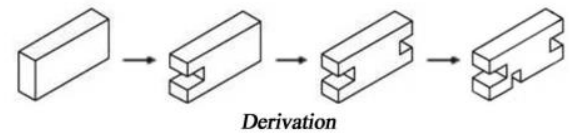

Gambar 2. Konsep Bentuk Porositas

Sumber: Kotsopoulos, 2007

\section{METODE}

Dalam melakukan studi, digunakan beberapa metode dalam pengumpulan data dan analisis. Berikut skema metode perancangan pada studi ini:

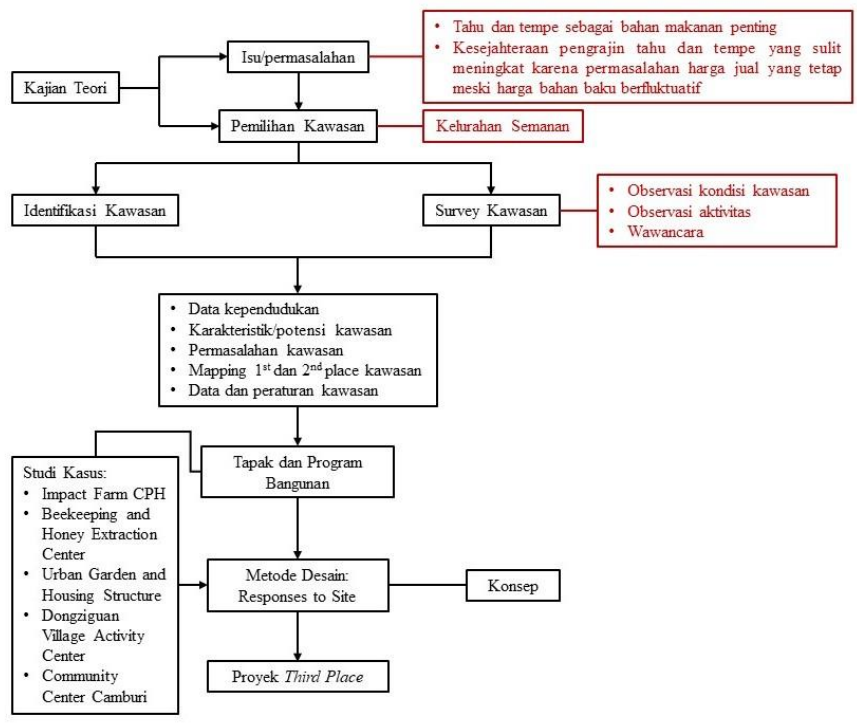

Gambar 3. Skema Metode Perancangan

Sumber: Penulis, 2020

Metode yang digunakan dalam pemngumpulan data dan analisis adalah metode observasi yang dilakukan dengan melihat secara langsung lingkungan di lapangan sehingga didapatkannya data-data kondisi eksisting kawasan dan metode wawancara yang dilakukan untuk mendapatkan informasi mengenai permasalahan yang ada pada kawasan.

Metode Perancangan yang digunakan adalah Responses to Site (Jormakka, 2008). Metode perancangan Responses to Site merupakan metode yang terbagi menjadi dua, yaitu:

a. Regionalism, dalam arsitektur mencoba untuk mengadaptasi dari beberapa bagian arsitektur dalam kawasan seperti pemakaian material lokal dan teknik konstruksinya yang tidak hanya untuk estetika tetapi juga untuk budaya lokal yang ada. Arsitektur Regionalism juga memperhatikan iklim, pencahayaan, pengudaraan, dan lainya sesuai dengan kawasannya. Dikutip dari artikel "Contextualism: Architecture and Context" Abdel-moniem El-shorbagy (2006), arsitektur regional harus dapat merespon tidak hanya terhadap karakteristik secara fisik pada suatu tempat atau kawasan, tetapi juga sosial, kultur dan politik, dan iklim dengan di dalam konteks modern.

b. Contextualism, dalam arsitektur mencoba untuk merespon karakteristik fisik khusus dari tapak atau kawasan. Arsitektur contextualism mengikuti morfologi dari 
lingkungan/kawasan, seperti sudut atap bangunan, axis jendela, tekstur, fasade bangunan, warna, dan lainnya dan mencoba untuk merekonstruksinya dengan karakter yang mirip. (Jormakka, 2008; Chuba, 2018)

\section{DISKUSI DAN HASIL}

\section{Analisis Program Kegiatan}

Penyusunan program kegiatan dalam rancangan third place didasarkan pada prinsip dan nilai pembangunan komunitas yang sustainable, yaitu sosial, ekonomi, dan lingkungan (Kasim, 2020) dan kondisi dan kebutuhan masyarakat Semanan khususnya komunitas pengrajin tahu dan tempe. Maka program bangunan yang dibentuk adalah community center (sosial), food market (ekonomi), dan outdoor space (lingkungan). Berikut merupakan skema program bangunan:

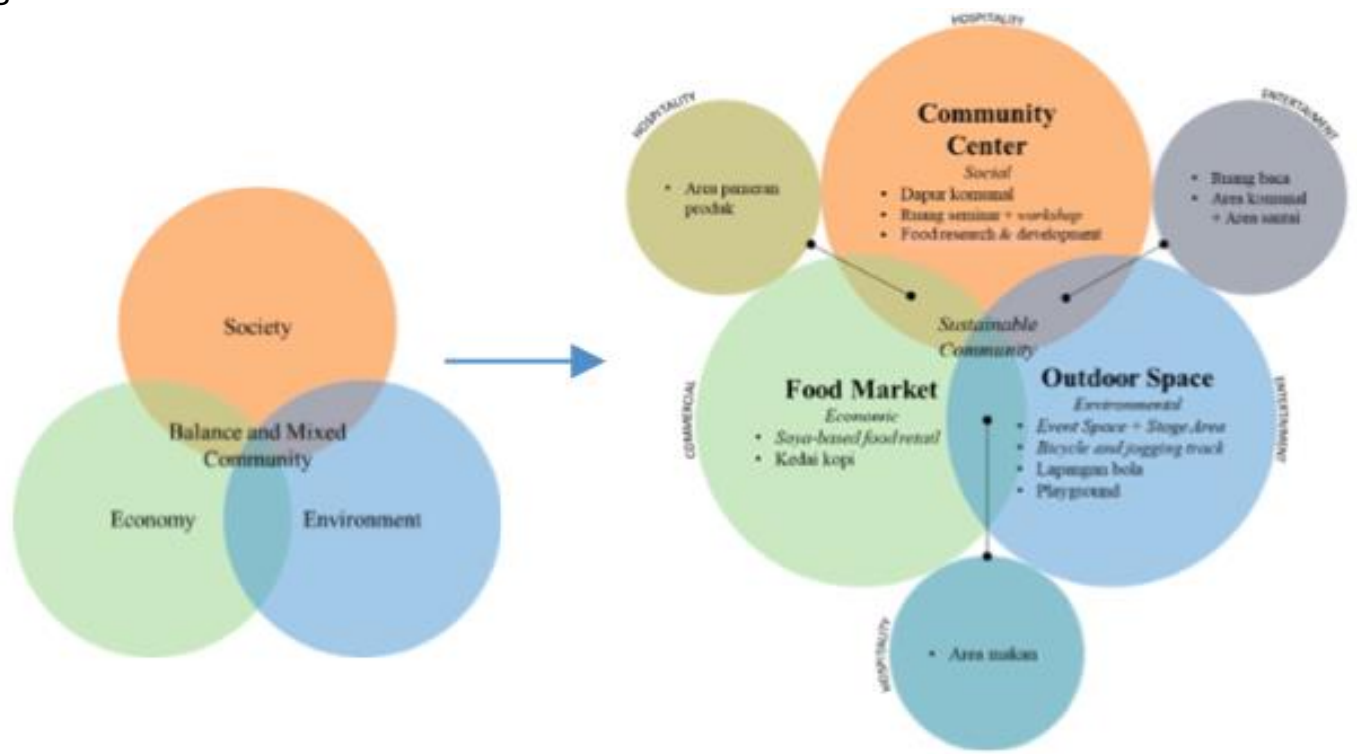

Gambar 4. Skematik Program Bangunan yang Sustainable Sumber: Kasim, 2020; Penulis, 2020
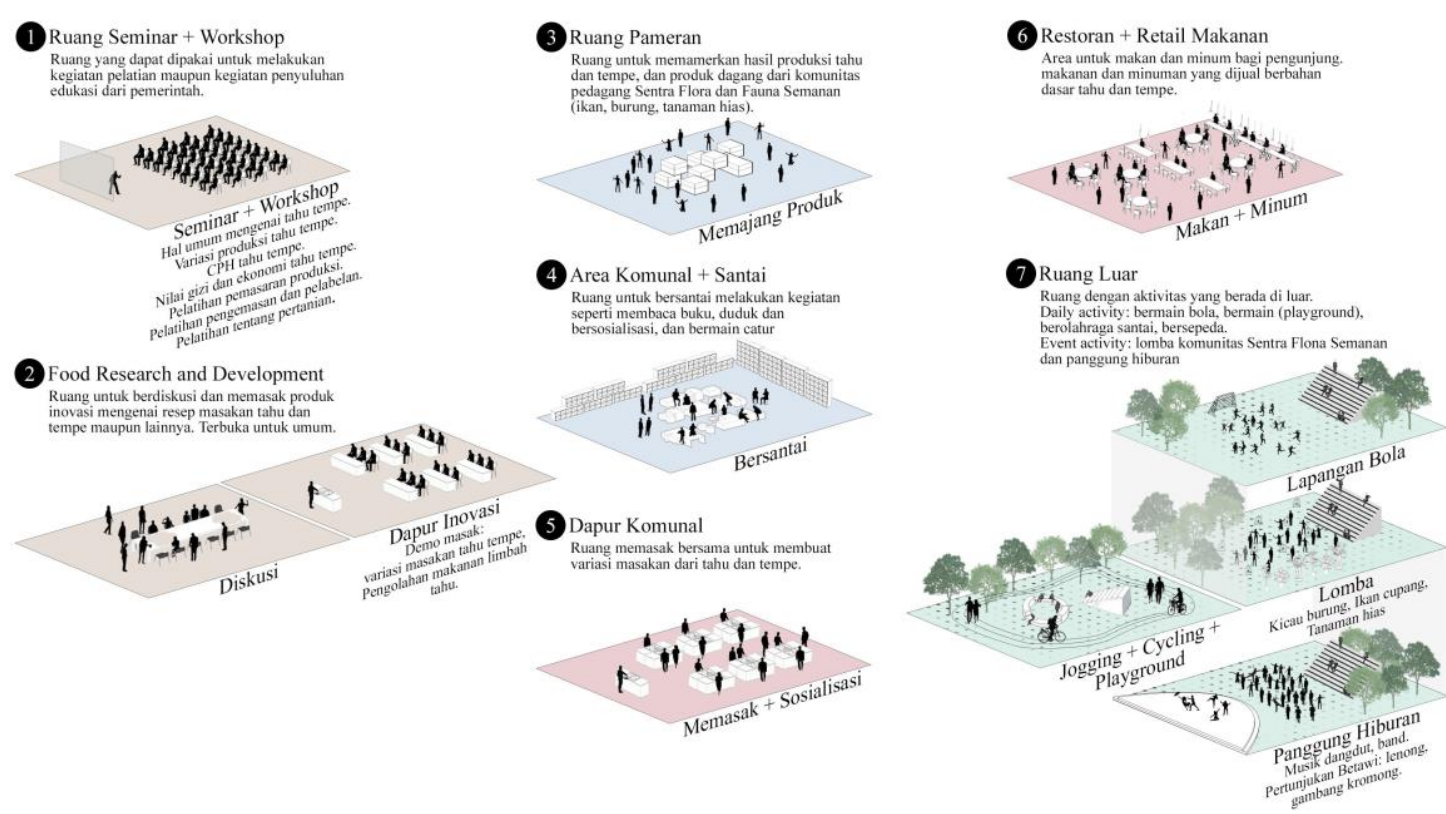

Gambar 5. Aktifitas Program Bangunan Sumber: Penulis, 2020 


\section{Community Center,}

Community Center mengandung nilai sosial dengan program ruang, yaitu:

a. Dapur komunal, ruang memasak bersama untuk membuat variasi masakan dari tahu dan tempe

b. Ruang seminar dan workshop, dapat dipakai baik untuk melakukan kegiatan pelatihan maupun kegiatan penyuluhan edukasi dari pemerintah

c. Ruang Food Reseach and Development, ruang untuk berdiskusi dan berinovasi mengenai resep masakan tahu dan tempe maupun lainnya. Terbuka untuk umum.

\section{Food Market}

Food Market, mengandung nilai ekonomi dan berfungsi sebagai area komersial. Dipadukan dengan program ruang, yaitu: Soya-based food retail, yang menjual produk olahan dari tahu tempe dan menjadi hasil industri olahan pengrajin tahu dan tempe di Perkampungan Industri Tahu Tempe.

\section{Outdoor Space}

Outdoor Space mengandung nilai lingkungan dan berfungsi sebagai area entertainment yang merupakan ruang untuk dilakukannya event bagi komunitas di Semanan. Ruang ini berada di luar dan merupakan ruang yang multifungsi sehingga kegiatan di dalamnya berubah-ubah. Program ruang pada Outdoor space, yaitu:

a. Daily activity: lapangan olah raga, bicycle and jogging track, playground dan sebagainya.

b. Event activity: berbagai kegiatan/event untuk komunitas misalnya Sentra Flona (aneka lomba kicau burung, ikan cupang, dan tanaman hias), panggung hiburan, dan kegiatan lain yang disukai masyarakat seperti musik dangdut, musik band, pertunjukan Betawi.

Secara bersama community center dan food market maka akan membentuk program ruang, yaitu: Ruang pameran, ruang untuk memamerkan hasil produksi tahu dan tempe, dan produk dagang dari komunitas pedagang Sentra Flora dan Fauna Semanan (ikan, burung, tanaman hias). Dipadukan dengan outdoor space maka akan membentuk program ruang, yaitu restoran, sebagai tempat untuk berkumpul, bersosialisasi dan menikmati makanan yang berbasis kedelai, tahu dan tempe. Sementara itu paduan aktivitas di community center dan outdoor space membentuk program ruang yang bersifat menghibur dan menyenangkan, ketika masyarakat dapat melakukan kegiatan untuk melepaskan lelah saat sedang istirahat maupun setelah pulang bekerja, yaitu:

a. Ruang buku dan baca, merupakan ruang yang berisikan bacaan mengenai tataboga dan pertanian.

b. Area komunal dan santai, merupakan area yang digunakan untuk bersantai, sekedar duduk dan bersosialisasi, berolahraga dan bermain catur.

\section{Analisis Lokasi Tapak}

Dalam memilih tapak untuk lokasi third place terdapat beberapa pertimbangan, yaitu:

a. Berada di antara first place (rumah) dan second place (tempat kerja). First Place dari Kelurahan Semanan, yaitu lingkungan perumahan dan Second place dari Kelurahan Semanan, yaitu kawasan pertanian, industri, dan perdagangan 


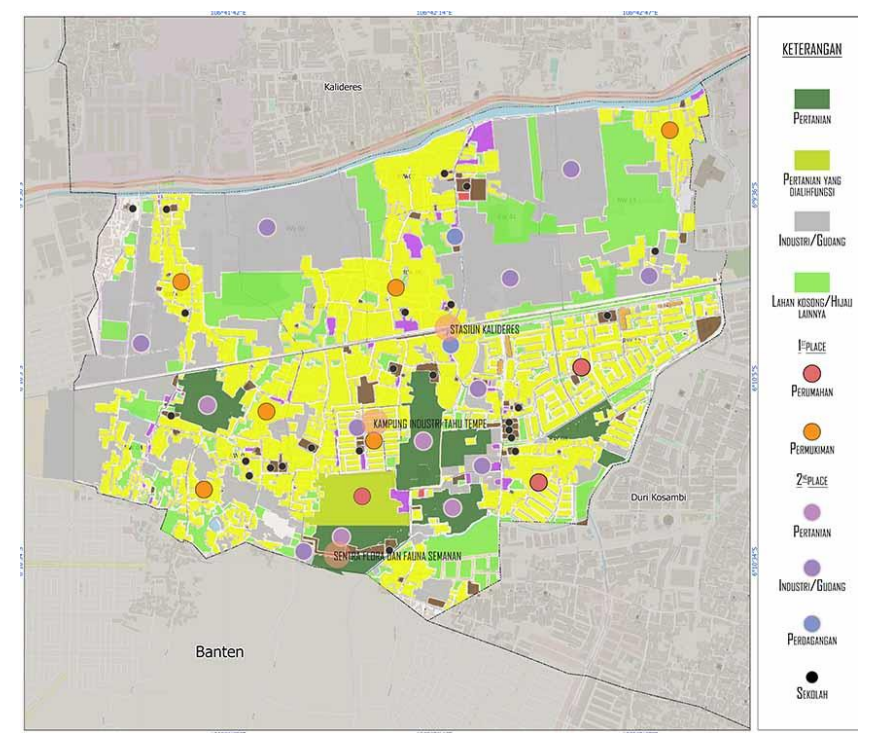

Gambar 6. Peta First Place dan Second Place di Kelurahan Semanan

Sumber: Penulis, 2020

a. Aksesibilitas transportasi umum dan walkable distance

b. Regulasi land use kawasan, yaitu zona ungu dengan fungsi perkantoran, perdagangan, dan jasa

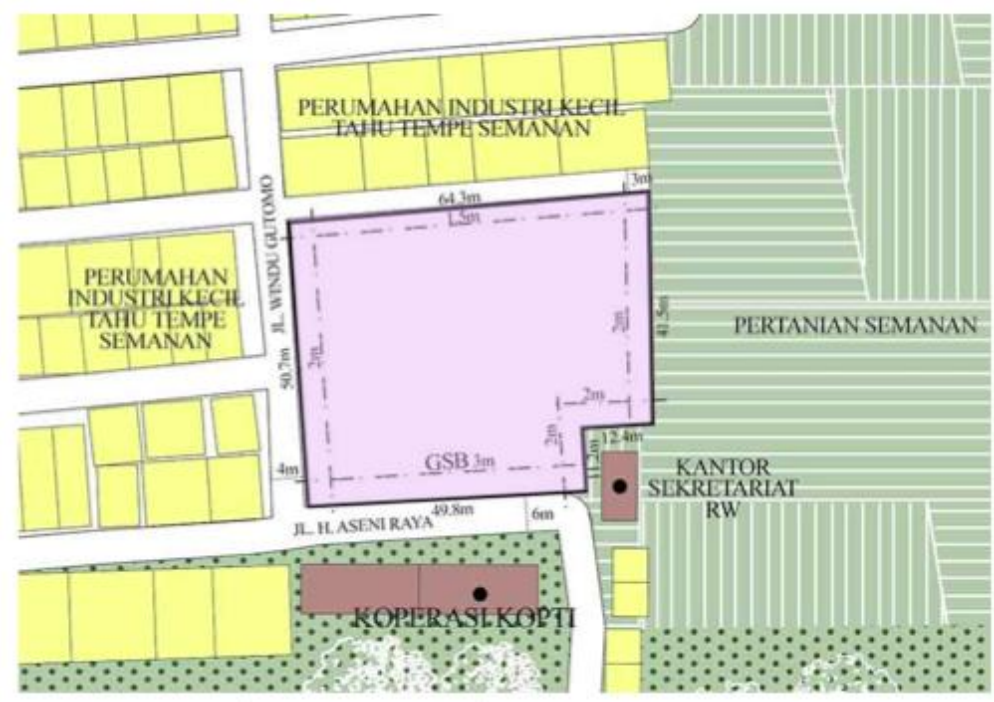

Gambar 7. Tapak Bangunan

Sumber: Penulis, 2020

Maka tapak yang terpilih berdasarkan pertimbangan tersebut, yaitu tapak yang berada di Jl. $\mathrm{H}$. Seni, RW 4, Semanan, Kalideres, Jakarta Barat dengan luas area sebesar $3.120 \mathrm{~m}^{2}$ dengan peraturan tapak:
a. Luas site
$: 3.120 \mathrm{~m}^{2}$
b. KDB
: $40=1.248 \mathrm{~m}^{2}$
c. KLB
$: 1.6=4992 \mathrm{~m}^{2}$
d. $K B$
$: 4$
e. $K D H$
$: 30=936 \mathrm{~m}^{2}$
f. KTB
$: 55=1716 \mathrm{~m}^{2}$
g. Jenis Kawasan: Fungsi perkantoran, perdagangan dan jasa 


\section{Konsep Bangunan}

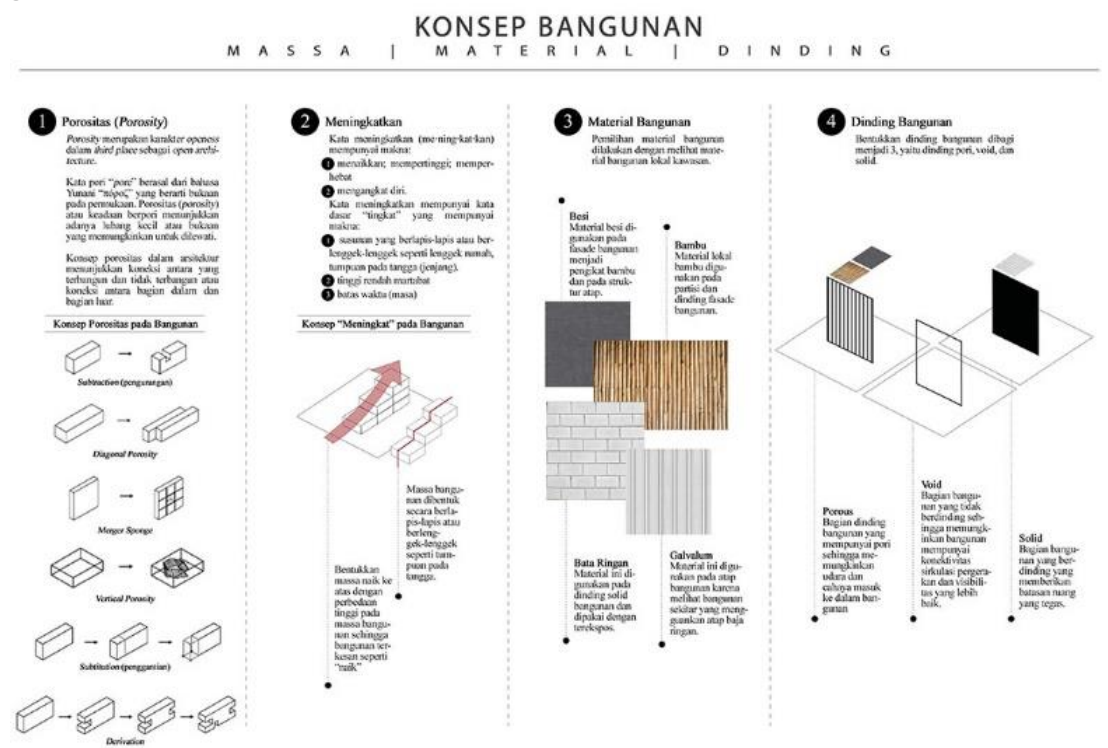

Gambar 8. Konsep Bangunan

Sumber: Penulis, 2020

Berikut merupakan konsep yang digunakan dalam pengolahan gubahan massa, material dan dinding bangunan:

a. Konsep Porosity

Konsep porositas merupakan konsep yang diambil dari karakter openness dalam third place sebagai open architecture. Konsep porosity dalam arsitektur menunjukkan konektivitas antara yang terbangun dan tidak terbangun serta antara bagian dalam dan bagian luar. Konsep ini memberikan pengudaraan, sirkulasi pencahayaan, aksesibilitas dan visibilitas, serta komunikasi antara ruang dalam dan luar yang lebih baik. (Kotsopoulos, 2007)

b. Konsep kata 'Meningkatkan'

Konsep meningkatkan ini merupakan konsep yang diambil dari tujuan atau visi dari proyek third place ini, yaitu meningkatkan kualitas kehidupan masyarakat Semanan dan komunitas pengrajin tahu tempe yang diterapkan dengan menguraikan makna dari kata "meningkatkan". Kata meningkatkan (me-ning-kat-kan) mempunyai makna menaikkan, mempertinggi dan mempunyai kata dasar "tingkat" yang artinya susunan yang berlapislapis seperti tangga. Dari makna kata tersebut maka konsep kata 'meningkatkan' pada bangunan ditunjukkan pada bentuk bangunan, dimana massa naik ke atas dan dibentuk secara berlapis-lapis.

\section{Konsep Gubahan Massa}

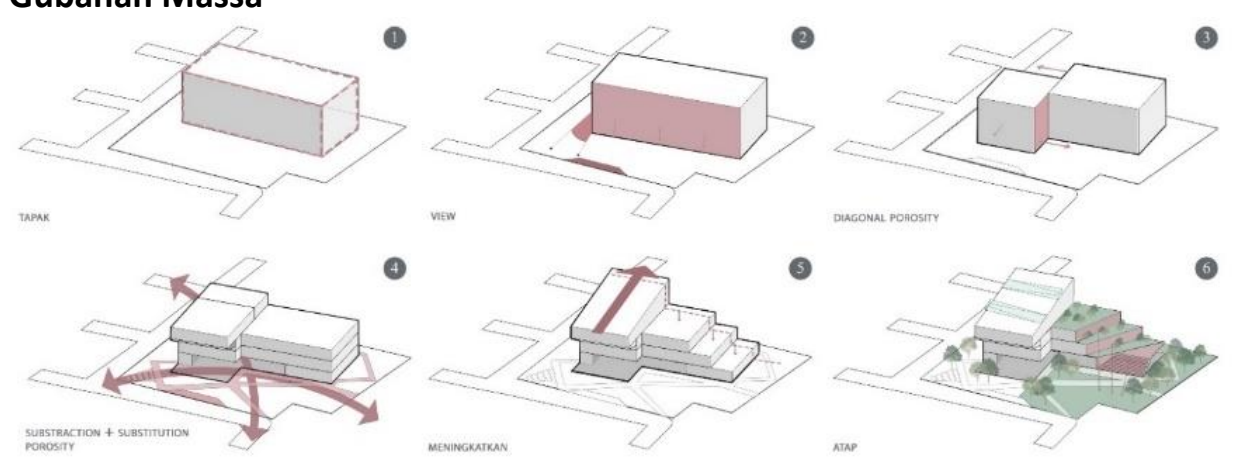

Gambar 9. Konsep Gubahan Massa

Sumber: Penulis, 2020 
Gubahan massa bangunan didasarkan pada konsep bangunan, yaitu porositas dan 'meningkatkan', serta pengolahan tapak yang kontekstual dengan dengan lingkungan sekitarnya sebagaimana pendekatan Responses to Site. Berikut proses gubahan massa yang terbagi menjadi enam tahapan:

a. Selain taat pada peraturan pembangunan setempat, dimensi dan pembentukan massa juga tanggap terhadap kondisi fisik lingkungan dan kondisi masyarakat sekitar tapak.

b. View bangunan, massa bangunan digeser sehingga massa menghadap menuju ke arah depan (arah sirkulasi datangnya user bangunan).

c. Diagonal Porosity, dengan diagonal porosity maka membentuk aksesibilitas dan koneksivitas antara ruang dalam dengan ruang luar serta memperkuat hubungan luar tapak dengan adanya transisi ruang luar yang didasarkan pada analisis sirkulasi tapak.

d. Substraction and Subtitution Porosity, dengan substraction dan substitution porosity pada massa bangunan dilakukan berdasarkan analisis sirkulasi pergerakan user maka pada lantai dasar bangunan menjadi terbuka dan bebas.

e. Meningkatkan, konsep meningkatkan artinya mempertinggi atau mengangkat diri dengan kata dasar tingkat yang berarti berlapis-lapis atau sebuah jenjang tangga sehingga bentuk massa menjadi berundak-undak seperti jenjang tangga.

f. Atap, massa dengan atap hijau (green rooftop) dibuat menghadap ke arah ruang luar sehingga menyatukan bangunan dengan ruang hijau sekitarnya. Pada ruang-ruang tertentu, digunakan skylight menggunakan material kaca (laminated glass) untuk mendapatkan pencahayaan dalam bangunan.

\section{Konsep Site Plan dan Aksesibilitas Bangunan}

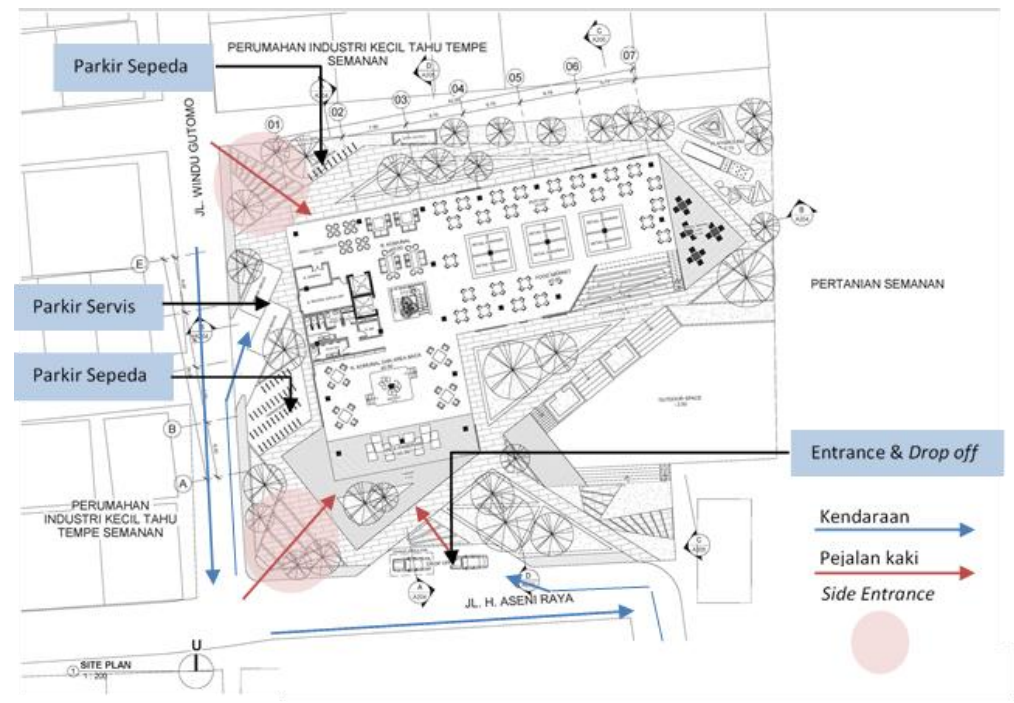

Gambar 10. Site Plan Bangunan

Sumber: Penulis, 2020

Tapak mengahadap ke arah Jl. H. Aseni Raya yang mempunyai lebar 6 meter dan berpotongan dengan J. Windu Gutomo yang mempunyai lebar 4 meter. Lebar jalan ini menjadi pertimbangan dari entrance depan dan drop-off kendaraan dari bangunan yang diletakkan pada J. H. Aseni Raya. Tidak adanya parkir pada tapak dikarenakan sasaran pegguna bangunan merupakan masyarakat Pemukiman Industri Kecil Semanan (first place) dan second place kawasan sehingga memudahkan aksesibilitas menuju ke bangunan. Pada drop-off kendaraan juga disediakan tempat untuk parkir mobil ambulans jika terjadi darurat. Jalan Windu Gutomo menjadi side entrance pejalan kaki, parkir sepeda, dan parkir servis untuk kendaraan servis. Taman pada side entrance untuk pejalan kaki menjadi transisi dari area luar tapak menuju ke dalam bangunan. Terdapat dua area untuk parkir sepeda yang diletakkan dekat dengan side entrance untuk memudahkan aksesibilitas pengguna sepeda. 


\section{Konsep Sirkulasi dan Zoning Bangunan}

Zoning bangunan menunjukkan hubungan dan peletakan ruang baik vertikal maupun horizontal yang mempengaruhi pergerakkan pengguna. Zoning bangunan terbagi menjadi enam, yaitu 1) zoning edukasi, 2) zoning kantor pengelola, 3) zoning dapur, 4) zoning area komunal, 5) zoning food market, dan 6) zoning ruang luar.

Sirkulasi bangunan menunjukkan pergerakan pejalan kaki dan kendaraan pada tapak yang dimana sebagai third place, bangunan lebih didesain untuk pejalan kaki dan pengguna sepeda karena mayoritas pengguna berasal dari lingkungan sekitar. Pergerakan orang di dalam bangunan dibuat menerus hingga ke luar bangunan dengan melalui tangga dan lift sehingga adanya konektivitas antara bagian luar dengan bagian dalam bangunan. Pada green rooftop, koneksi antar tangga dari seating-stair mendorong masyarakat menuju ke atas tanpa harus mempunyai tujuan.

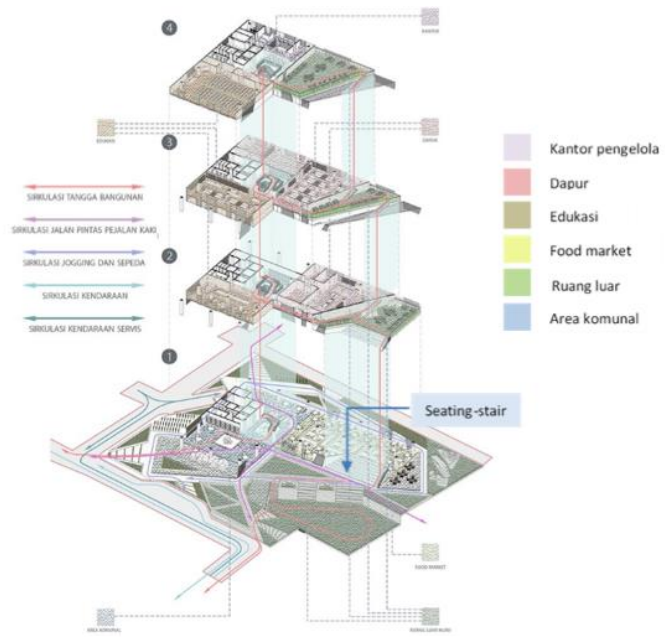

Gambar 11. Zoning dan Sirkulasi Bangunan Sumber: Penulis, 2020

\section{Konsep Pola Ruang Luar Bangunan}

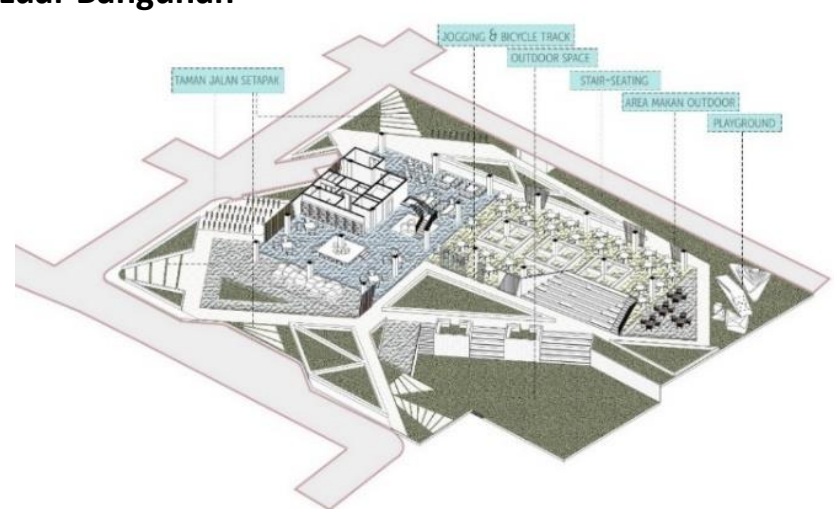

Gambar 12. Ruang Luar Bangunan Sumber: Penulis, 2020

Area ruang luar merupakan area yang mempunyai karakter third place playful mood, memberikan suasana yang nyaman dan menyenangkan bagi pengguna karena adanya interaksi sosial. Area ruang luar terdiri dari outdoor space, jogging dan bicycle track, stair-seating, dan playground. Outdoor space diletakkan di bagian depan tapak untuk menjadi area yang mendorong masyarakat masuk ke dalam bangunan sehingga terkesan terbuka dan menyambut. Stair-seating diletakkan mengahadap ke outdoor space agar orang dapat menikmati event yang terjadi pada outdoor space. 
Jogging dan bicycle track dirancang mengelilingi bangunan untuk memaksimalkan panjang jalur dan sekaligus sebagai penghubung dengan transisi jalan setapak dan taman yang didasarkan pada analisis pergerakan orang. Area playground untuk anak-anak diletakkan dekat dengan food market agar anak-anak tetap berada pada pengawasan ketika orang tua sedang bersantai. Antara food market dan playground terdapat area makan luar yang berfungsi sebagai ruang transisi.

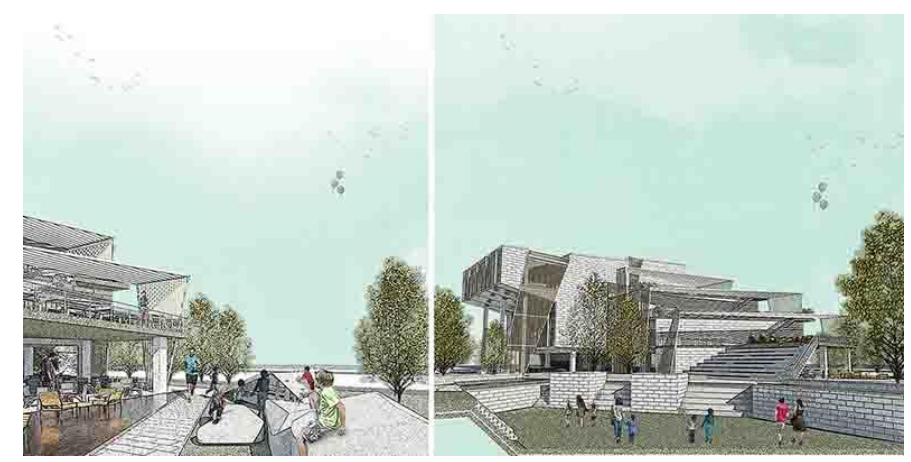

Gambar 13. Perspektif Playground dan Outdoor Space

Sumber: Penulis, 2020

\section{Konsep Program Ruang}

Berikut besaran ruang yang terbagi dalam enam kelompok (community area, outdoor space, food market, kantor, servis, dan parkir):

Tabel 1 Luas Kebutuhan Ruang

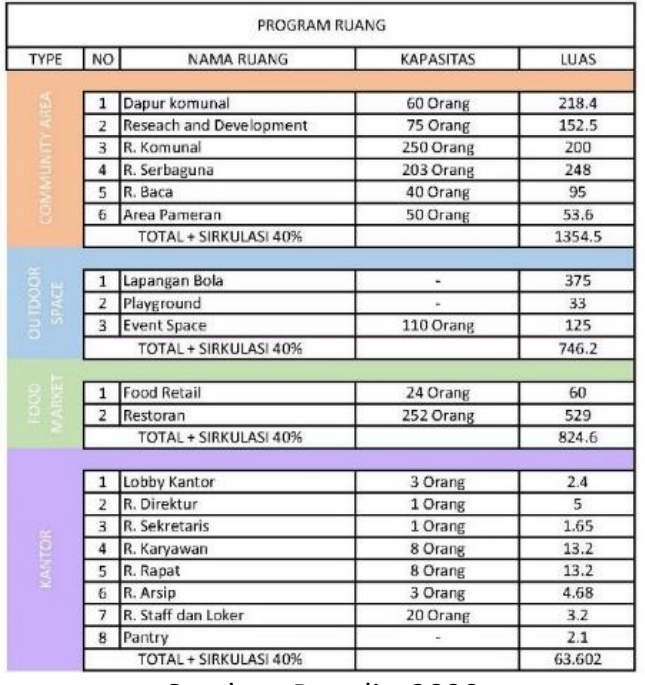

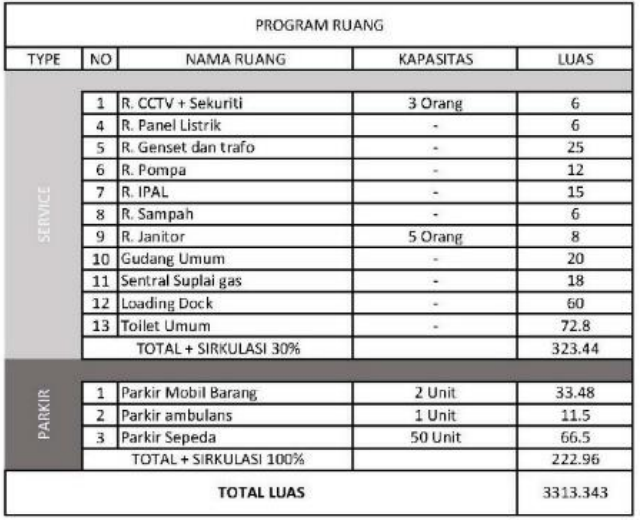

Sumber: Penulis, 2020

\section{Desain Ruang Dalam Bangunan}

Ruang di dalam bangunan third place mempunyai karakter netral, level, conversation, accessible, dan regular yang menunjukkan aktivitas yang bersifat komunal dan dapat diakses oleh umum, terutama masyarakat lokal Semanan. Dalam aspek pencahayaan dan pengudaraan, setiap ruang mendapatkan pencahayaan dan pengudaraan alami baik dari bukaan dinding maupun dari atap kaca bangunan. Dapur Komunal, dapur food research and development, ruang diskusi food research and development, serta ruang serbaguna merupakan ruang yang difungsikan untuk inovasi, edukasi, serta interaksi sosial melalui aktivitas memasak makanan berbasis tahu dan tempe bersama sehingga ruangan didesain terbuka untuk memaksimalkan interaksi masyarakat. 


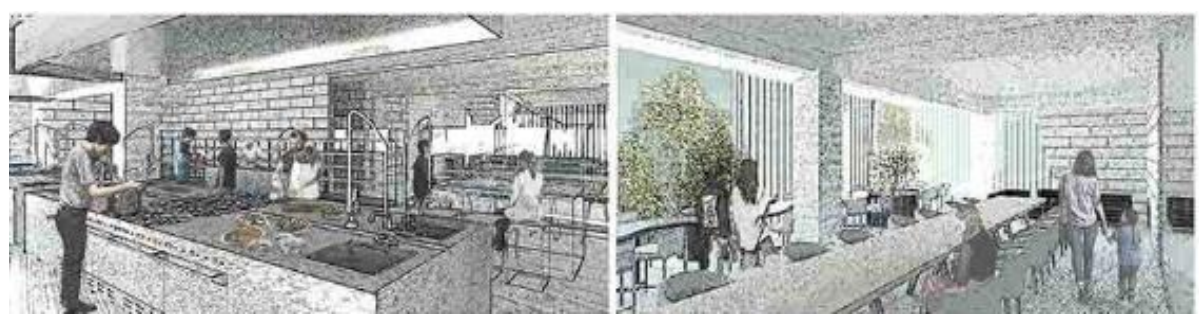

Gambar 14. Perspektif Dapur dan Ruang Diskusi Food Research and Development

Sumber: Penulis, 2020

Perbedaan sifat aktivitas mempengaruhi penataan furniture pada dapur food research and development yang digunakan untuk berinovasi dan edukasi sehingga meja dapur dibuat berhadapan antara pengajar dan pelajar dan jumlah meja dapur yang lebih sedikit dibandingkan dengan dapur komunal yang digunakan untuk produksi. Meja panjang dan sofa pada ruang diskusi food research and development difungsikan untuk berdiskusi inovasi makanan tahu dan tempe. Ruang serbaguna difungsikan untuk kegiatan seminar yang diadakan oleh pemerintah atau lembaga lainnya. Mempunyai tata ruang yang memanjang dengan kapasitas kursi 200 orang. Untuk mengantisipasi panas dari atap kaca maka digunakannya skylight blinds sehingga ruangan tetap mendapatkan pencahayaan matahari secara tidak langsung.

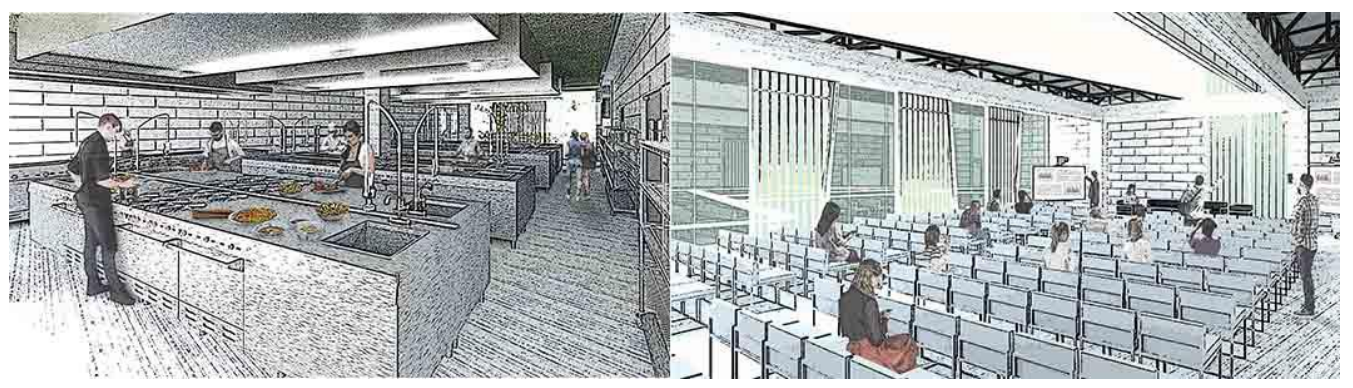

Gambar 15. Perspektif dapur komunal dan ruang serbaguna

Sumber: Penulis, 2020

Hasil inovasi produk yang didapatkan kemudian dijual dan dipromosikan pada food market dan area pameran di lantai dasar bangunan dimana ruangan dibuat terbuka sehingga menjadi wadah masyarakat untuk bersosialisasi dan bersantai. Untuk meningkatkan pemasaran produk maka area pameran pada ruang komunal diletakkan di bagian depan bangunan. Antara ruang dalam bangunan dengan luar bangunan mempunyai batasan yang buram sehingga adanya konektivitas antara keduanya. Selain di food market, Area Green rooftop juga difungsikan untuk area makan sehingga menjadi daya tarik bagi masyarakat untuk menggunakannya.

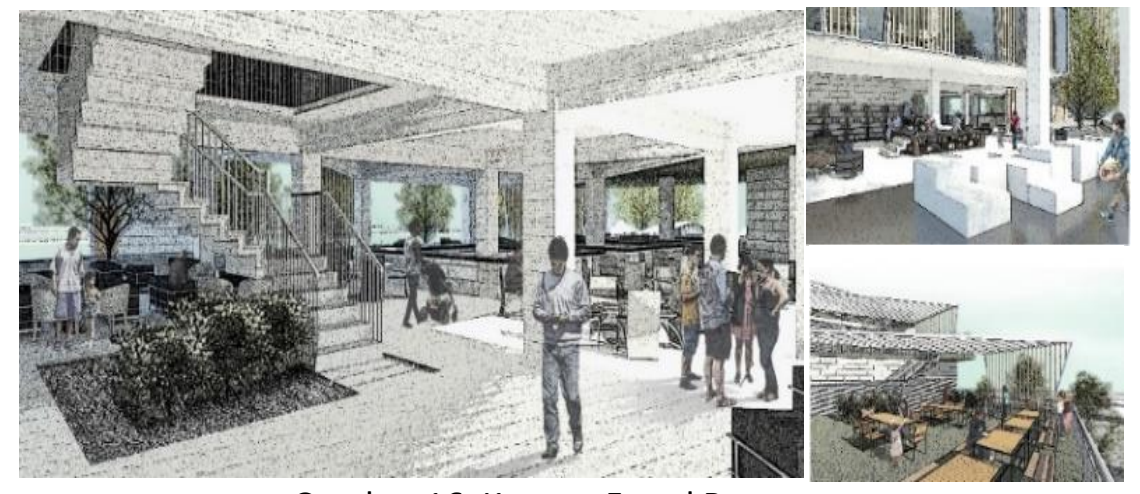

Gambar 16. Konsep Fasad Bangunan

Sumber: Penulis, 2020 


\section{Konsep Fasade dan Material Bangunan}
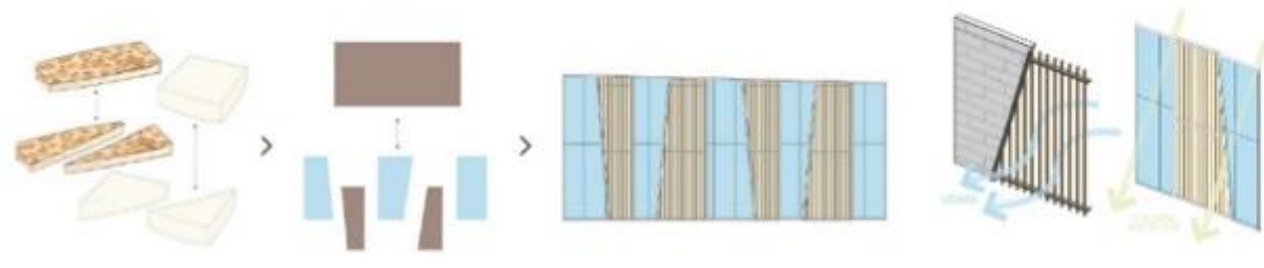

Gambar 17. Konsep Fasad Bangunan

Sumber: Penulis, 2020

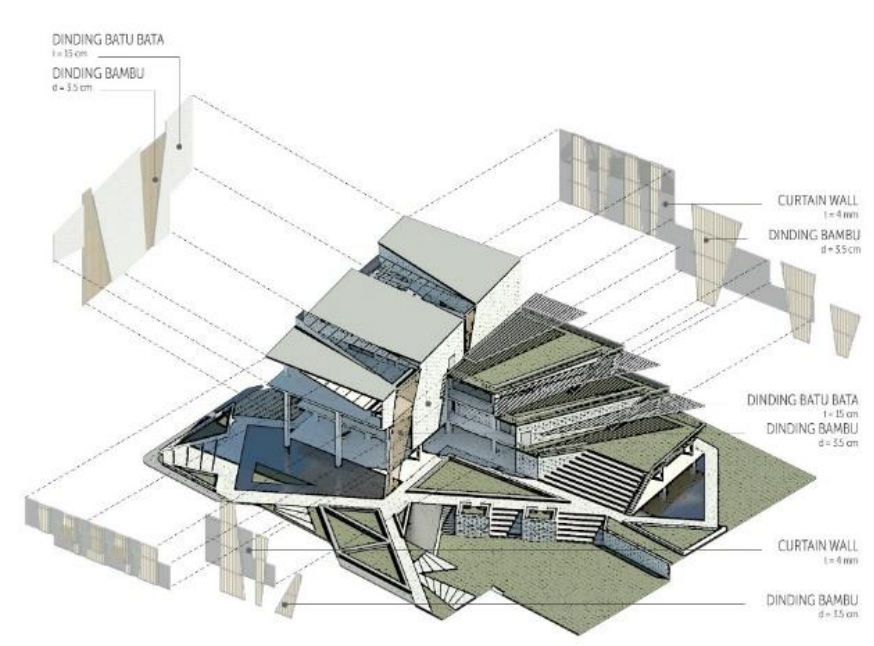

Gambar 18. Aksonometri Material Fasad Bangunan Sumber: Penulis, 2020

Fasade bangunan mempunyai konsep dari tempe dan tahu yang terpotong. dari konsep tersebut maka dibuat bentuk geometrisnya yang kemudian dipotong secara diagonal sehingga terbentuk fasade dinding pengisi yang menggunakan material batu-bata, bambu, dan curtain wall. Material bambu dengan dibentuk poros (berpori) digunakan sebagai jalur pengudaraan alami. Material batu bata digunakan pada sisi barat dan timur bangunan sedangkan material curtain wall digunakan pada sisi utara dan selatan bangunan sehingga bangunan mendapatkan pencahayaan alami matahari.

\section{KESIMPULAN DAN SARAN}

Studi tentang perancangan third place di Permukiman Industri Tahu Tempe ini menghasilkan suatu rancangan Proyek Wadah Hiburan, Inovasi dan Edukasi Tataboga Tahu Tempe di Semanan dan diharapkan menjadi jawaban akan permasalahan dan kebutuhan masyarakat Semanan terutama pengrajin tahu dan tempe. Dengan program community center yang terdiri dari dapur komunal dan food research and development, food market, dan outdoor space maka dapat membantu meningkatkan kesejahteraan masyarakat melalui pengembangan hasil produksi lokal, bantuan pemasaran, inovasi dan edukasi serta interaksi sosial untuk masyarakat. Bangunan dengan konsep porosity membuat adanya konektivitas dengan bangunan sekitarnya sehingga bangunan tersebut kontekstual dengan kawasan dan terbuka kepada masyarakat Semanan. Kontekstualitas bangunan juga terlihat pada pemilihan material lokal seperti bambu, besi, bata ringan, dan galvalum sehingga bangunan sebagai third place dapat beradaptasi dengan lingkungannya. Dengan desain ini maka masyarakat diharapkan akan merasa nyaman dan tidak takut untuk masuk ke dalam bangunan seperti karakter third place, plain and unpretentious. Konsep tahu dan tempe pada fasade juga menjadikan ciri bagi bangunan yang menunjukkan Permukiman Industri Kecil Semanan sebagai karakteristik dari kawasan Semanan. 


\section{REFERENSI}

Azanella, L. A. (2019). Sejarah Tempe, Makanan Kaya Protein yang Lahir dari Era Tanam Paksa. Retrieved February 27, 2020, from Kompas: https://www.kompas.com/tren/read/2019/09/07/170000265/sejarah-tempe-makanankaya-protein-yang-lahir-dari-era-tanam-paksa?page=all

Badan Pusat Statistik, SUSENAS. (2018). Pengeluaran untuk Konsumsi Penduduk Indonesia per Provinsi 2018. DKI Jakarta.

Badan Pusat Statistik, SUSENAS. (2018). Rata-rata Konsumsi per Kapita Seminggu Beberapa Macam Bahan Makanan Penting. DKI Jakarta

Chuba, C \& Jon-nwakalo, C. (2018). Discourse on Contextualism in Architecture and Design: The French Hotels and the African Paradigm.

Jormakka, K. (2008). Basic Design Methods. Basel: Birkhäuser

Kasim, Rozilah \& Ahmad, Abd. Razak \& Eni, Sabariah. (2020). The neighbourhood facilities and the sustainable communities agenda: an overview.

Kotsopoulos, S. (2007). Design Concepts in Architecture: the Porosity Paradigm.

Sicca, S. P. (2018). Menyelamatkan Pengrajin Tahu Tempe dari Ancaman Melemahnya Rupiah. Retrieved Februari 27, 2020, from Tirto.id: https://tirto.id/menyelamatkan-pengrajin-tahutempe-dari-ancaman-melemahnya-rupiah-cXXr

Sulistiowati, T. (2018). Melongok Kampung UKM Terbesar di Jakarta. Retrieved February 7, 2020, from Kontan: https://peluangusaha.kontan.co.id/news/melongok-kampung-ukmterbesar-di-jakarta-1 
